\title{
Depression and anxiety in patients recently recovered from coronavirus disease (COVID-19)
}

\author{
Objawy depresji i lęku u pacjentów po przebyciu choroby koronawirusowej \\ (COVID-19)
}

\author{
Rafał Dankowski', Wioletta Sacharczuk¹, Dominika Duszyńska', Weronika Mikołajewska', \\ Anna Szałek-Goralewska', Anna Łojko-Dankowska², Andrzej Szyszka1 ${ }^{1}$, Dorota Łojko ${ }^{3}$ \\ ${ }^{1} 2^{\text {nd }}$ Department of Cardiology, Poznan University of Medical Sciences, Poznań, Poland \\ 2Department of Hematology and Bone Marrow Transplantation, Poznan University of Medical Sciences, Poznań, Poland \\ ${ }^{3}$ Department of Adult Psychiatry, Poznan University of Medical Sciences, Poznań, Poland
}

Neuropsychiatria i Neuropsychologia 2021; 16, 1-2: 11-16

\author{
Address for correspondence: \\ Rafał Dankowski, MD, PhD \\ $2^{\text {nd }}$ Department of Cardiology \\ Poznan University of Medical Sciences \\ 28 Czerwca 1956 r. no. 194 \\ 61-485 Poznań, Poland \\ phone: +48 612274160 \\ e-mail: rafaldan@ump.edu.pl
}

\section{Abstract}

Aim of the study: To evaluate the presence and severity of anxiety and depressive symptoms in patients who recently recovered from coronavirus disease 2019 (COVID-19).

Material and methods: In this cross-sectional observational study, patients who had recovered from COVID-19 were assessed between February and April 2021. The symptoms reported by patients were evaluated using a questionnaire developed by the authors based on the National Institute for Health and Care Excellence (NICE) guidelines. The Beck Depression Inventory (BDI) and the State-Trait Anxiety Inventory (STAI) were used to assess their depressive symptoms and anxiety.

Results: Of the 102 patients, 45 (44\%) were men, and the mean age ( \pm standard deviation $-\mathrm{SD}$ ) was 52 \pm 13 years. The mean time interval $( \pm S D)$ between COVID-19 diagnosis and the examination was 56 \pm 18 days. Seventy-eight $(76 \%)$ patients were treated at home, while $24(23.5 \%)$ were hospitalized. Fatigue, cognitive impairment ("brain fog"), breathlessness, and cough were the most frequently reported complaints. Median scores of the BDI, state-anxiety (STAI 1) and trait-anxiety (STAI 2) were 7 (interquartile range, $\mathrm{IQR}=10), 38(\mathrm{IQR}=13)$, and $40.5(\mathrm{IQR}=14)$, respectively. Mild depressive symptoms were observed in almost $30 \%$ of patients. Women scored significantly higher than men.

Conclusions: Patients who have recently recovered from COVID-19 show increased anxiety and depressive symptoms, the intensity of which was more pronounced in women. From the clinical perspective, physicians should be aware of the anxiety and depressive symptoms of the post-COVID-19 syndrome.

\section{Streszczenie}

Cel pracy: Ocena występowania objawów lęku i depresji w grupie pacjentów, którzy przeszli chorobę koronawirusową (COVID-19).

Materiał i metody: W przekrojowym badaniu obserwacyjnym w okresie od lutego do kwietnia $2021 \mathrm{r}$. przebadano pacjentów, którzy niedawno przebyli chorobę koronawirusową (COVID-19), co najmniej $28 \mathrm{dni}$ od rozpoznania. Objawy zgłaszane przez pacjentów były oceniane za pomocą kwestionariusza opracowanego na podstawie wytycznych Narodowego Instytutu Doskonałości Zdrowia i Opieki (NICE, Wielka Brytania). Pacjenci byli badani z użyciem Inwentarza depresji Becka (Beck Depression Inventory - BDI) oraz Inwentarza stanu $i$ cechy lęku (State-Trait Anxiety Inventory - STAI) w celu oceny objawów depresji i lęku.

Wyniki: W badanej grupie 102 osób było 45 mężczyzn (44\%), średnia wieku ( \pm odchylenie standardowe - SD) wynosiła $52 \pm 13$ lat. Średni czas $( \pm S D)$, jaki upłynął od diagnozy COVID-19 do badania, wynosił $56 \pm 18$ dni. Spośród 102 ozdrowieńców, 78 (76\%) było leczonych w domu, podczas gdy $24(23,5 \%)$ osoby byly hospitalizowane. Najczęściej zgłaszanymi dolegliwościami były zmęczenie, zaburzenia funkcji poznawczych (,,mgła mózgowa”), duszność i kaszel. Mediana wyników dla BDI, lęku jako stanu (STAI 1) i lęku jako cechy (STAI 2) wyniosła odpowiednio 7 (rozstęp kwartylowy, IQR $=10$ ), $38(\mathrm{IQR}=13)$ i $40,5(\mathrm{IQR}=14)$. Lagodne objawy depresji zaobserwowano u prawie $30 \%$ pacjentów. Odnotowano istotnie wyższe wyniki BDI, STAI 1 i STAI 2 u kobiet w porównaniu z mężczyznami.

Wnioski: Pacjenci, którzy niedawno przebyli COVID-19, wykazują zwiększone nasilenie lęku i objawy depresji. Objawy są bardziej wyrażone u kobiet. Z klinicznego punktu widzenia lekarze powinni być świadomi ob- 
Key words: COVID-19, BDI, STAI, anxiety, depression.

\section{Introduction}

Since the outbreak of coronavirus disease 2019 (COVID-19) in December 2019, we have been witnessing the greatest pandemic in recent years. As of May 25, 2021, over 167 million global cases have been reported (Worldometer 2021). COVID-19 is associated with a substantial risk of hospitalization and death (Wang et al. 2020). The pandemic created a previously unknown reality symbolized by facemasks, lockdown and social distancing. All these issues significantly affect the psychosocial dimension of life (Torales et al. 2020) as well as mental health in the general population (Xiong et al. 2020) and vulnerable groups (Suwalska et al. 2021; Tasnim et al. 2021).

The meta-analysis conducted in 2020 shows that the estimated pooled prevalence of depression increased from $3.44 \%$ in 2017 to $25 \%$ in 2020 (Bueno-Notivol et al. 2021). Moreover, according to a recently published study, $18 \%$ of COVID-19 patients developed a psychiatric disorder up to 3 months after their diagnosis (Taquet et al. 2021).

Following the acute phase of the disease, COVID-19 may have chronic consequences. Indeed, patients who have recovered from severe acute respiratory syndrome coronavirus 2 (SARS-CoV-2) infection may present various sequelae (Al-Aly et al. 2021).

Previous studies showed that chronic diseases, such as diabetes mellitus, cancer, or heart disease, are related to higher rates of depression and anxiety (Berge et al. 2019; Cohen et al. 2019; Pitman et al. 2018). At present, however, the severity of anxiety and depression in post-COVID-19 patients remains largely unknown.

The Beck Depression Inventory (BDI) is a well-established tool for assessing depressive symptoms (Beck et al. 1961). Likewise, the StateTrait Anxiety Inventory (STAI) is a commonly used instrument for measuring trait and state anxiety (Spielberger et al. 1983). Both of these inventories are commonly used when assessing patients with different diseases. The BDI was previously used to assess depressive symptoms in patients with various neurological diseases such as multiple sclerosis and in cancer patients (Cvetkovic and Nenadovic 2016; Tauil et al. jawów depresji i lęku występujących u pacjentów po przechorowaniu COVID-19.

Słowa kluczowe: COVID-19, BDI, STAI, lęk, depresja.

2018). The STAI was previously used when assessing anxiety in patients with chronic stroke or suffering from cancer (Chun et al. 2017; Eskelinen and Ollonen 2011).

\section{Aim of the study}

The present study evaluated the severity of anxiety and depression in patients who had recovered from COVID-19 using the Beck Depression Inventory and State-Trait Anxiety Inventory.

\section{Material and methods}

\section{Study design and patients}

The study was designed as a single-center, cross-sectional study. This substudy, designed to assess the severity of depression and anxiety, was a part of a more extensive research project evaluating post-COVID-19 sequelae. We defined post-COVID-19 sequelae (or post-acute COVID-19 syndrome) as persistent symptoms and/or delayed or long-term complications of SARS-CoV-2 infection beyond four weeks from the diagnosis of COVID-19 (Nalbandian et al. 2021). The examination of patients was conducted in the $2^{\text {nd }}$ Department of Cardiology, St. John Paul II HCP Hospital in Poznan. Primary care physicians in Poznan recruited ambulatory patients who had recently recovered from COVID-19. The reason for referral was the evaluation after the COVID-19 infection. The assessment of patients took place between February 9 and April 16, 2021. Inclusion criteria were as follows: age $>18$ years, confirmed COVID-19 infection by SARS-CoV-2 realtime PCR using nasopharyngeal swabs at least 28 days before the assessment. We included patients either treated at home or hospitalized due to COVID-19. We set the following exclusion criteria: severe mental disorders (dementia, schizophrenia, bipolar disorders, schizoaffective disorders), auditory and visual disability. In order to assess post-acute COVID-19 symptoms, we developed a questionnaire based on the National Institute for Health and Care Excellence (NICE) guidelines (NICE 2020). The questionnaire consisted of 24 questions ("yes/no" answers) regarding the current symptoms. Patients completed the questionnaire on their own. 


\section{Self-reported symptoms of anxiety}

Anxiety was measured with the Polish adaptation of the State-Trait Anxiety Inventory (STAI) (Sosnowski et al. 2011). The STAI is a 40-item self-assessment scale measuring the presence and severity of current symptoms of anxiety and a generalized propensity to be anxious. The STAI is divided into two subscales; each of them contains 20 items. First, the State Anxiety Scale (S-Anxiety or STAI 1) evaluates the current state of anxiety, asking how respondents feel "right now". It uses items that measure subjective feelings of apprehension, tension, nervousness, worry, and activation/arousal of the autonomic nervous system. The second subscale - the Trait Anxiety Scale (T-Anxiety or STAI 2) - evaluates relatively stable aspects of "anxiety proneness", including general states of confidence, calmness and security. Responses for the S-Anxiety scale assess the intensity of current feelings "at this moment": 1) not at all, 2) somewhat, 3) moderately so, and 4) very much so. Responses for the T-Anxiety scale assess the frequency of feelings "in general": 1) almost never, 2) sometimes, 3) often, and 4) almost always. The STAI has been used in several chronic medical conditions (Julian 2011).

\section{Assessment of depressive symptoms}

We used the Polish adaptation of the Beck Depression Inventory (BDI) (Parnowski and Jernajczyk 1977) to assess depressive symptoms. The BDI is a self-reported, 21-question test for measuring the presence and severity of symptoms of depression in the preceding two weeks. The BDI contains 21 items on a 4-point scale from 0 (symptom absent) to 3 (severe symptoms). It covers affective, cognitive, somatic and vegetative symptoms of depression, reflecting the criteria for major depression. Higher scores indicate greater symptom severity (JacksonKoku 2016).

All patients signed informed consent before entering the study. The Bioethics Commission of Poznan University of Medical Sciences approved the study. The study complies with the requirements of the Declaration of Helsinki.

\section{Statistical analysis}

The distribution of data was tested for normality using the Shapiro-Wilk test. Continuous data are presented as mean and standard deviation (SD) or median and interquartile range (IQR) when data were non-normally distributed.
Categorical variables are expressed as numbers and percentages. Student's $t$-test or the Mann-Whitney $U$-test was applied for the group comparison. Correlations were evaluated by the Pearson or Spearman correlation coefficient. Statistical significance was considered for values of $p<0.05$. We performed all analyses using the data analysis software system Statistica, version 13 (TIBCO Software Inc., 2017).

\section{Results}

Characteristics of the study group are shown in Table 1. We excluded three patients from the initially included 105 patients: one patient did not complete the STAI questionnaire correctly, one patient had the examination 120 days after COVID-19, and one patient had a BDI result of 41 and was referred to a psychiatrist. Finally, the analyzed group consisted of 102 patients, 55 women $(55.9 \%)$, with a mean age of 51.9 \pm 13.4 years. $24(23.6 \%)$ hospitalized patients had moderate to severe COVID-19 disease (Rochwerg et al. 2020). However, none of the patients was in a critical stage of COVID-19, requiring admission to the intensive care unit, intubation or heart-lung machine or extracorporeal membrane oxygenation (ECMO) support. The average time ( \pm SD) from the diagnosis of COVID-19 was $55 \pm 18$ days. Table 2 shows the occurrence of post-COVID-19 symptoms. Fatigue (82.4\%), cognitive impairment (52.9\%),

Table 1. Characteristics of the study group

\begin{tabular}{|c|c|}
\hline \multicolumn{2}{|l|}{ Variable } \\
\hline Number of patients & 102 \\
\hline Males/females, $n(\%)$ & $45(44) / 57(56)$ \\
\hline Age (years $\pm S D$ ) & $52 \pm 13$ \\
\hline $\begin{array}{l}\text { Number of days since COVID-19 } \\
\text { diagnosis } \pm \text { SD }\end{array}$ & $56 \pm 18$ \\
\hline $\begin{array}{l}\text { Number of patients hospitalized } \\
\text { for COVID-19 (\%) }\end{array}$ & $24(23.5)$ \\
\hline \multicolumn{2}{|l|}{ Comorbidities, $n$ (\%) } \\
\hline Hypertension & $37(36.3)$ \\
\hline Hypothyroidism & $13(12.7)$ \\
\hline Diabetes mellitus & $10(9.8)$ \\
\hline $\begin{array}{l}\text { Asthma/chronic obstructive pulmo- } \\
\text { nary disease }\end{array}$ & $8(7.8)$ \\
\hline Dyslipidemia & $6(5.9)$ \\
\hline $\begin{array}{l}\text { History of depression/anxiety } \\
\text { disorders }\end{array}$ & $5(4.9)$ \\
\hline Ischemic heart disease & $3(2.9)$ \\
\hline
\end{tabular}


Rafał Dankowski, Wioletta Sacharczuk, Dominika Duszyńska, Weronika Mikołajewska, Anna Szałek-Goralewska, Anna Łojko-Dankowska, Andrzej Szyszka, Dorota Łojko

Table 2. Symptoms after COVID-19 (sorted by frequency)

\begin{tabular}{ll} 
Symptom & $\begin{array}{c}\text { Number of patients } \\
\text { (\%) }\end{array}$ \\
Fatigue & $84(82.4)$ \\
\hline Cognitive impairment ("brain fog”) & $54(52.9)$ \\
\hline Breathlessness & $43(42.2)$ \\
\hline Cough & $43(42.2)$ \\
\hline Chest tightness & $38(37.3)$ \\
\hline Sleep disorders & $38(37.3)$ \\
\hline Peripheral neuropathy symptoms & $36(35.3)$ \\
\hline Anxiety & $34(33.3)$ \\
\hline Palpitations & $30(29.4)$ \\
\hline Headache & $29(28.4)$ \\
\hline Loss of taste/smell & $29(28.4)$ \\
\hline Muscle pain & $28(27.5)$ \\
\hline Dizziness & $24(23.5)$ \\
\hline Joint pain & $23(22.5)$ \\
\hline Chest pain & $22(21.6)$ \\
\hline Tinnitus & $18(17.6)$ \\
\hline Depressive symptoms & $17(16.7)$ \\
\hline Pain & $11(11.8)$ \\
\hline Sore throat & $9(8.8)$ \\
\hline Abdominal pain & $7(6.9)$ \\
\hline Skin rashes & $4.9)$ \\
\hline Diarrhea & \\
\hline Earache & \\
\hline Nausea & \\
\hline & \\
\hline
\end{tabular}

breathlessness (42.2\%) and cough (42.2\%) were most frequently reported. The median number of the reported symptoms was six (IQR $=6$, $\min =0, \max =16$ ). Women reported significantly more symptoms than men $(8, \mathrm{IQR}=5$ vs. 5, IQR $=4$, respectively, $p=0.007)$.

BDI and STAI 1 results were non-normally distributed. BDI results were left-skewed; STAI 1 results were slightly right-skewed. The median BDI score for the whole group was $7(\mathrm{IQR}=10)$, the median STAI 1 score was $38(\mathrm{IQR}=13)$, and the median STAI 2 score was $40.5(\mathrm{IQR}=14)$. Women had significantly higher scores of BDI, STAI 1 and STAI 2 (Table 3). Categorized BDI results are shown in Table 4. A BDI score $\leq 11$ was observed in $72(70.6 \%)$ patients. In this group, only four patients reported no symptoms suggestive of depression (BDI score $=0$ ). The median score in this group was $5(\mathrm{IQR}=5)$. Twenty-nine (28.4\%) had a score corresponding to mild depression (BDI score $\geq 12$ and $\leq 26$ ), and one patient (1\%) had symptoms of moderate to severe depression (BDI score $>26$ ).

BDI, STAI 1 and STAI 2 scores showed high correlation (Table 5, Spearman's $\rho>0.75$, $p<0.001)$.

There were a moderate correlation between the number of post-COVID-19 symptoms and BDI, STAI 1 and STAI 2 results (Table 6).

Hospitalized patients had significantly higher BDI scores. There was no significant difference regarding STAI 1 and STAI 2 in hospitalized vs. non-hospitalized patients (Table 7).

\section{Discussion}

To the best of our knowledge, this is the first study assessing the severity of depression and anxiety in Polish patients who have recovered from COVID-19. Our results show that almost $30 \%$ of patients present symptoms related to mild depression (BDI score $\geq 12$ and $\leq 26$ ). Moreover, in the group in which the BDI score was below 12 , only four patients reported no symptoms. The median score in this group was $5(\mathrm{IQR}=5)$. The median BDI score was significantly higher in women (Table 3). This finding corresponds with previous studies before the COVID-19 outbreak. According to a systematic review and meta-analysis of post-COVID-19 symptoms (Lopez-Leon et al. 2021), $13 \%$ of those patients suffer from depression, and $12 \%$ complain of anxiety. In the recently published paper by de Sá Junior et al. (2019) women had higher scores of BDI-II than men.

Table 3. BDI, STAI 1 and STAI 2 scores

\begin{tabular}{lcccc} 
& All $(\boldsymbol{N}=102)$ & Men $(n=45)$ & Women $(n=57)$ & $p$ (men vs. women) \\
BDI (IQR) & $7(10)$ & $7(7)$ & $9(11)$ & 0.046 \\
\hline STAI 1 (IQR) & $38(13)$ & $35(14)$ & $40(13)$ & 0.02 \\
\hline STAI 2 (IQR) & $40.5(14)$ & $36(13)$ & $45(13)$ & $<0.01$ \\
\hline
\end{tabular}


Table 4. Categorized BDI results

\begin{tabular}{lc} 
BDI score & $\begin{array}{c}\text { Number of patients } \\
\text { (\%) }\end{array}$ \\
$\leq 11$ (no depression) & $72(70.6)$ \\
\hline$\geq 12$ and $\leq 26$ (mild depression) & $29(28.4)$ \\
\hline $\begin{array}{l}>26 \text { (moderate-severe } \\
\text { depression) }\end{array}$ & $1(1.0)$ \\
\hline
\end{tabular}

Table 6. Correlation between number of symptoms and BDI, STAI 1 and STAI 2 results

\begin{tabular}{lcc} 
Variables & Spearman's $\rho$ & $p$ \\
$\begin{array}{l}\text { Number of symptoms } \\
\text { and BDI score }\end{array}$ & 0.47 & $<0.001$ \\
\hline $\begin{array}{l}\text { Number of symptoms } \\
\text { and STAl 1 score }\end{array}$ & 0.49 & $<0.001$ \\
\hline $\begin{array}{l}\text { Number of symptoms } \\
\text { and STAI 2 score }\end{array}$ & 0.47 & $<0.001$ \\
\hline
\end{tabular}

We also found a correlation between the number of symptoms and higher BDI scores. Furthermore, hospitalized patients had higher BDI scores than non-hospitalized ones. These findings could be related to the content of the BDI. Some of the items of the BDI concern the symptoms observed after COVID-19. For example, questions about being annoyed or about difficulties in decision-making can be connected with COVID-19-related neurological changes described as brain fog (Nakamura et al. 2021).

The BDI questionnaire concerns issues related to physical problems such as pain, upset stomach, and constipation. Again, all these problems are common three months after being diagnosed with COVID-19 (Al-Aly et al. 2021). Differences regarding BDI scores in hospitalized and non-hospitalized patients may reflect the distress resulting from the strict isolation for a long time. Furthermore, many patients feel uncertain about the state of their health and the future.

To evaluate the anxiety level, we used the STAI 1 and STAI 2 inventory. The median STAI 1 score was 38 (IQR = 13), and the median STAI 2 score was $40.5(\mathrm{IQR}=14)$. These results indicate that patients had a moderate level of anxiety. The results were similar or even lower than mean results in the population during the COVID-19 pandemic, where the mean result was $50.3 \pm 7.4$ (Madkor $e$ t al. 2021). Our study showed that females had greater anxiety level than males. Hishinuma et al. (2000) also observed such a difference, where female and male students were tested.
Table 5. Correlation between BDI, STAI 1 and STAI 2 scores

\begin{tabular}{lcc} 
Variables & Spearman's $\rho$ & $p$ \\
BDI and STAI 1 score & 0.75 & $<0.001$ \\
\hline BDI and STAI 2 score & 0.80 & $<0.001$ \\
\hline STAI 1 and STAI 2 score & 0.86 & $<0.001$ \\
\hline
\end{tabular}

Table 7. BDI, STAI 1 and STAI 2 in hospitalized vs. non-hospitalized patients

\begin{tabular}{lccc}
$\begin{array}{l}\text { Inventory } \\
\text { type }\end{array}$ & $\begin{array}{c}\text { Non-hospitali- } \\
\text { zed patients } \\
(n=78)\end{array}$ & $\begin{array}{c}\text { Hospitalized } \\
\text { patients } \\
(n=24)\end{array}$ & $p$ \\
BDI (IQR) & $6.5(7)$ & $10.5(13.5)$ & 0.02 \\
\hline STAI 1 (IQR) & $38(14)$ & $41.5(18)$ & 0.19 \\
\hline STAI 2 (IQR) & $40(13)$ & $42.5(16)$ & 0.26 \\
\hline
\end{tabular}

The limitation of our study is its cross-sectional design. To assess whether experiencing COVID-19 can affect depression and anxiety level, the study should be prospective. Our study cannot exclude the background increase of anxiety and depression related to the COVID-19 pandemic. A recent study by Solomou and Constantinidou (2020) revealed that during the pandemic, $23.1 \%$ of responders reported moderate-to-severe anxiety symptoms. Concerning depression, $48 \%$ reported mild and 9.2\% moderate-to-severe depression symptoms.

\section{Conclusions}

Patients recently recovered from COVID-19 present elevated anxiety and depressive symptoms. In this regard, women are more affected. From the clinical point of view, physicians should be aware of the depressive and anxiety symptoms of the post-COVID-19 syndrome. It is necessary to address (identify and treat) them, minimize the risk of progression to the chronic state, and help re-establish the pre-COVID-19 health status.

\section{Disclosure}

The authors declare no conflict of interest.

\section{References}

1. Al-Aly Z, Xie Y, Bowe B. High-dimensional characterization of post-acute sequelae of COVID-19. Nature 2021; 594: 259-264.

2. Beck AT, Ward CH, Mendelson M, et al. An inventory for measuring depression. Arch Gen Psychiatry 1961; 4: 561-571. 
3. Berge T, Bull-Hansen B, Solberg EE, et al. Screening for symptoms of depression and anxiety in a cardiology department. Tidsskr Nor Laegeforen 2019; 139.

4. Bueno-Notivol J, Gracia-Garcia P, Olaya B et al. Prevalence of depression during the COVID-19 outbreak: A meta-analysis of community-based studies. Int J Clin Health Psychol 2021; 21: 100196.

5. Chun MH, Chang MC, Lee SJ. The effects of forest therapy on depression and anxiety in patients with chronic stroke. Int J Neurosci 2017; 127: 199-203.

6. Cohen A, Peleg O, Sarhana A, et al. Depressive symptoms mediate the relationship between emotional cutoff and type 2 diabetes mellitus. Int I Behav Med 2019; 26: 591-599.

7. Cretkovic J, Nenadovic M. Depression in breast cancer patients. Psychiatry Res 2016; 240: 343-347.

8. De Sá Junior AR, Liebel G, De Andrade AG, et al. Can gender and age impact on response pattern of depressive symptoms among college students? A differential item functioning analysis. Front Psychiatry 2019; 10: 50.

9. Eskelinen M, Ollonen P. Assessment of general anxiety in patients with breast disease and breast cancer using the Spielberger STAI self evaluation test: a prospective case-control study in Finland. Anticancer Res 2011; 31: 1801-1806.

10. Hishinuma ES, Miyamoto RH, Nishimura ST, et al. Psychometric properties of the state-trait anxiety inventory for Asian/Pacific-islander adolescents. Assessment 2000; 7: 17-36.

11. Jackson-Koku G. Beck Depression Inventory. Occup Med (Lond) 2016; 66: 174-175.

12. Julian LJ. Measures of anxiety: State-Trait Anxiety Inventory (STAI), Beck Anxiety Inventory (BAI), and Hospital Anxiety and Depression Scale-Anxiety (HADS-A). Arthritis Care Res (Hoboken) 2011; 63 Suppl 11: S467-472.

13. Lopez-Leon S, Wegman-Ostrosky T, Perelman C, et al. More than 50 long-term effects of COVID-19: a systematic review and meta-analysis. medRxiv 2021.

14. Madkor ORE, Elsorady KE, Abdelhady DH, et al. COVID-19 Life Events-Anxiety Inventory (C-19LAI): development, reliability, and validity study on Egyptian population. Middle East Curr Psychiatry 2021; 28: 21.

15. Nakamura ZM, Nash RP, Laughon SL, et al. Neuropsychiatric complications of COVID-19. Curr Psychiatry Rep 2021; 23: 25 .

16. Nalbandian A, Sehgal K, Gupta A, et al. Post-acute COVID-19 syndrome. Nat Med 2021; 27: 601-615.

17. National Institute for Health and Care Excellence (NICE). COVID-19 rapid guideline: managing the long-term effects of COVID-19 [Online]. National Institute for Health and Care Excellence (NICE), London 2020. Available: https://www.nice.org.uk/guidance/ng188 (accessed January, 12, 2021).

18. Parnowski T, Jernajczyk W. Inwentarz Depresji Becka w ocenie nastroju osób zdrowych i chorych na choroby afektywne. Psychiatr Pol 1977; 11: 417-421.

19. Pitman A, Suleman S, Hyde N, et al. Depression and anxiety in patients with cancer. BMJ 2018; 361: k1415.

20. Rochwerg B, Siemieniuk RA, Agoritsas T, et al. A living WHO guideline on drugs for covid-19. BMJ 2020; 370: m3379.

21. Solomou I, Constantinidou F. Prevalence and predictors of anxiety and depression symptoms during the COVID-19 pandemic and compliance with precautionary measures: age and sex matter. Int I Environ Res Public Health 2020; 17: 4924.
22. Sosnowski T, Jaworowska A, Fecenec D. STAI - Inwentarz Stanu i Cechy Lęku. Psychological Test Laboratory of the Polish Psychological Association, Warsaw 2011.

23. Spielberger CD, Gorsuch RL, Lushene R, et al. Manual for the State-Trait Anxiety Inventory. Consulting Psychologists Press, Palo Alto, CA 1983.

24. Suwalska J, Napierała M, Bogdański P, et al. Perinatal mental health during COVID-19 pandemic: an integrative review and implications for clinical practice. I Clin Med 2021; 10: 2406.

25. Taquet M, Luciano S, Geddes JR, et al. Bidirectional as sociations between COVID-19 and psychiatric disorder: retrospective cohort studies of 62354 COVID-19 cases in the USA. Lancet Psychiatry 2021; 8: 130-140.

26. Tasnim R, Sujan MSH, Islam MS, et al. Prevalence and correlates of anxiety and depression in frontline healthcare workers treating people with COVID-19 in Bangladesh. BMC Psychiatry 2021; 21: 271.

27. Tauil CB, Grippe TC, Dias RM, et al. Suicidal ideation, anxiety, and depression in patients with multiple sclerosis. Arq Neuropsiquiatr 2018; 76: 296-301.

28. Torales J, O'Higgins M, Castaldelli-Maia JM, et al. The outbreak of COVID-19 coronavirus and its impact on global mental health. Int I Soc Psychiatry 2020; 66: 317-320.

29. Wang Y, Chen Y, Qin Q. Unique epidemiological and clinical features of the emerging 2019 novel coronavirus pneumonia (COVID-19) implicate special control measures. J Med Virol 2020; 92: 568-576.

30. Worldometer, 2021. COVID-19 coronavirus pandemic [Online]. Available: https://www.worldometers.info/coronavirus/ (accessed May 25, 2021).

31. Xiong J, Lipsitz O, Nasri F, et al. Impact of COVID-19 pandemic on mental health in the general population: A systematic review. J Affect Disord 2020; 277: 55-64. 